\title{
MECHANISM AND CLINICAL IMPORTANCE OF RESPIRATORY FAILURE INDUCED BY ANTICHOLINESTERASES
}

Anita Ivosevic ${ }^{1}$, Natasa Miletic ${ }^{2}$, Maja Vulovic ${ }^{3 *}$, Zoran Vujkovic ${ }^{4}$, Snjezana Novakovic Bursac ${ }^{5}$, Slavko S. Cetkovic ${ }^{6}$, Ranko Skrbic ${ }^{7}$, and Milos P. Stojiljkovic ${ }^{2,7}$ ${ }^{1}$ Department of Internal Medicine, Faculty of Medical Sciences, University of Kragujevac, Kragujevac, Serbia

${ }^{2}$ Medical Faculty, University of East Sarajevo, Foča, Republic of Srpska, Bosnia \& Herzegovina

${ }^{3}$ Department of Anatomy and Forensic Medicine, Faculty of Medical Sciences, University of Kragujevac, Kragujevac, Serbia

${ }^{4}$ Neurology Clinic, University Clinical Centre of Republic of Srpska, Medical Faculty, University of Banja Luka, Banja Luka, Republic of Srpska, Bosnia \& Herzegovina

${ }^{5}$ Institute for Physical Medicine and Rehabilitation „Dr Miroslav Zotovic“, Banja Luka, Republic of Srpska, Bosnia \& Herzegovina ${ }^{6}$ Military Medical Academy, Belgrade, Serbia

${ }^{7}$ Department of Pharmacology, Toxicology \& Clinical Pharmacology, Medical Faculty, University of Banja Luka, Banja Luka, Republic of Srpska, Bosnia \& Herzegovina

\section{MEHANIZAM II KLINIČKA VAŽNOST RESPIRATORNE INSUFICIJENCIJE IZAZVANE ANTIHOLINESTERAZAMA}

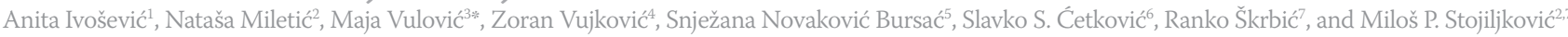 \\ ${ }^{1}$ Katedra za internu medicinu, Fakultet medicinskih nauka, Univerzitet u Kragujevcu, Kragujevac, Srbija \\ ${ }^{2}$ Medicinski fakultet, Univerzitet u Istočnom Sarajevu, Foča, Republika Srpska, Bosna i Hercegovina \\ ${ }^{3}$ Institut za anatomiju i sudsku medicinu, Fakultet medicinskih nauka, Univerzitet u Kragujevcu, Kragujevac, Srbija \\ ${ }^{4}$ Klinika za neurologiju, Univerzitetski klinički centar Republike Srpske, Medicinski fakultet, Univerzitet u Banja Luci, Banja Luka, \\ Republika Srpska, Bosna i Hercegovina \\ ${ }^{5}$ Zavod za fizikalnu medicinu i rehabilitaciju „Dr Miroslav Zotović“, Banja Luka, Republika Srpska, Bosna i Hercegovina \\ Vojnomedicinska akademija, Beograd, Srbija \\ Zavod za farmakologiju, toksikologiju i kliničku farmakologiju, Medicinski fakultet, Univerzitet u Banja Luci, Banja Luka \\ Republika Srpska, Bosna i Hercegovina
}

\section{ABSTRACT}

Respiratory failure is the predominant cause of death in humans and animals poisoned with anticholinesterases. Organophosphorus and carbamate anticholinesterases inhibit acetylcholinesterase irreversibly and reversibly, respectively. Some of them contain a quaternary atom that makes them lipophobic, limiting their action at the periphery, i.e. outside the central nervous system. They impair respiratory function primarily by inducing a desensitization block of nicotinic receptors in the neuromuscular synapse. Lipophilic anticholinesterases inhibit the acetylcholinesterase both in the brain and in other tissues, including respiratory muscles. Their doses needed for cessation of central respiratory drive are significantly less than doses needed for paralysis of the neuromuscular transmission. Antagonist of muscarinic receptors atropine blocks both the central and peripheral muscarinic receptors and effectively antagonizes the central respiratory depression produced by anticholinesterases. To manage the peripheral nicotinic receptor hyperstimulation phenomena, oximes as acetylcholinesterase reactivators are used. Addition of diazepam is useful for treatment of seizures, since they are cholinergic only in their initial phase and can contribute to the occurrence of central respiratory depression. Possible involvement of central nicotinic receptors as well as the other neurotransmitter systems - glutamatergic, opioidergic - necessitates further research of additional antidotes.

Keywords: Anticholinesterase, Acetylcholinesterase, Acetylcholine, Atropine, Oxime, Diazepam, Respiratory depression, Muscarinic receptors, Nicotinic receptors

\section{SAŽETAK}

Respiratorna insuficijencija je dominantan uzrok smrti kod ljudi $i$ životinja trovanih antiholinesterazama. Organofosphorne $i$ karbamatske antiholinesteraze inhibišu acetilholinesterazu ireverzibilno, odnosno reverzibilno. Neke od njih sadrže kvaternerni atom koji ih čini lipofobnim, čime im ograničava delovanje na periferiju, tj. van centralnog nervnog sistema. One oštećuju respiratornu funkciju primarno izazivajući desenzitizujući blok nikotinskih receptora u neuromuskularnoj sinapsi. Lipofilne antiholinesteraze inhibišu acetilholinesterazu i u mozgu i u drugim tkivima, uključujući i respiratorne mišiće. Njihove doze neophodne za prekidanje centralnog respiratornog generatora impulsa su značajno niže od doza potrebnih za paralizu neuromuskularne transmisije. Antagonist muskarinskih receptora atropin blokira i centralne i periferne muskarinske receptore $i$ efektiveno antagonizuje centralnu respiratornu depresiju izazvanu antiholinesterazama. U cilju kupiranjahiperstimulacije perifernih nikotinskih receptora koriste se oksimi, kao reaktivatori acetilholinesteraze. Dodavanje diazepama je korisno u tretmanu konvulzija, pošto su one holinergičke samo u svojoj početnoj fazi i mogu da doprinesu pojavi respiratorne depresije. Moguća umešanost centralnih nikotinskih receptora, kao i drugih neurotransmiterskih sistema - glutamatergičkog $i$ opioidergičkog - zahteva dalje istraživanje dodatnih antidota.

Ključne reči: Antiholinesteraze, Acetilholinesteraza, Acetilholin, Atropin, Oksim, Diazepam, Respiratorna depresija, Muskarinski receptori, Nikotinski receptori 


\section{ACETYLCHOLINE, ACETYLCHOLINESTERASE AND THEIR PHYSIOLOGICAL FUNCTIONS}

Acetylcholine is a neurotransmitter of vital importance in the central nervous system (CNS), but also peripherally, i.e. in the vegetative nervous system (VNS) ganglia and at the endings of the postganglionic parasympathetic fibers, such as heart, smooth muscle cells and exocrine glands (1). A specifically important role of acetylcholine is to mediate transmission at the neuromuscular junction of skeletal muscles (2).

When the action potential reaches the motoneuron ending, it opens the voltage-dependent calcium channels and causes the influx of calcium ions into the nerve ending. As a result, acetylcholine vesicles fuse with the presynaptic membrane and the neurotransmitter is released into the synaptic cleft by exocytosis. After reaching the postsynaptic membrane, acetylcholine binds to nicotinic receptors and opens the sodium channels. The ensuing influx of sodium cations into the skeletal muscle cell triggers the action potential that reaches the myofibrils and causes a muscle contraction (3). All these details are shown in Figure 1.
Acetylcholinesterase (AChE) is an enzyme located in cholinergic synapses within the synaptic cleft. It is very active, which means that it breaks down the molecules of acetylcholine into choline and acetate in split-second assuring thus that there is no surplus of acetylcholine to induce the overstimulation of the cholinergic receptors located at the postsynaptic membrane (2).

While in the CNS the types of cholinergic receptors or cholinoceptors through which acetylcholine exerts its action are believed to be both muscarinic and nicotinic, this division is much simpler at the periphery - muscarinic receptors are located at the endings of postganglionic parasympathetic fibers, while nicotinic ones are located in the both sympathetic and parasympathetic ganglia and at the neuromuscular junction $(1,2)$.

\section{ANTICHOLINESTERASES AND THEIR MODE OF ACTION}

Acetylcholinesterase (AChE) inhibitors or anticholinesterases comprise various chemical entities whose com-

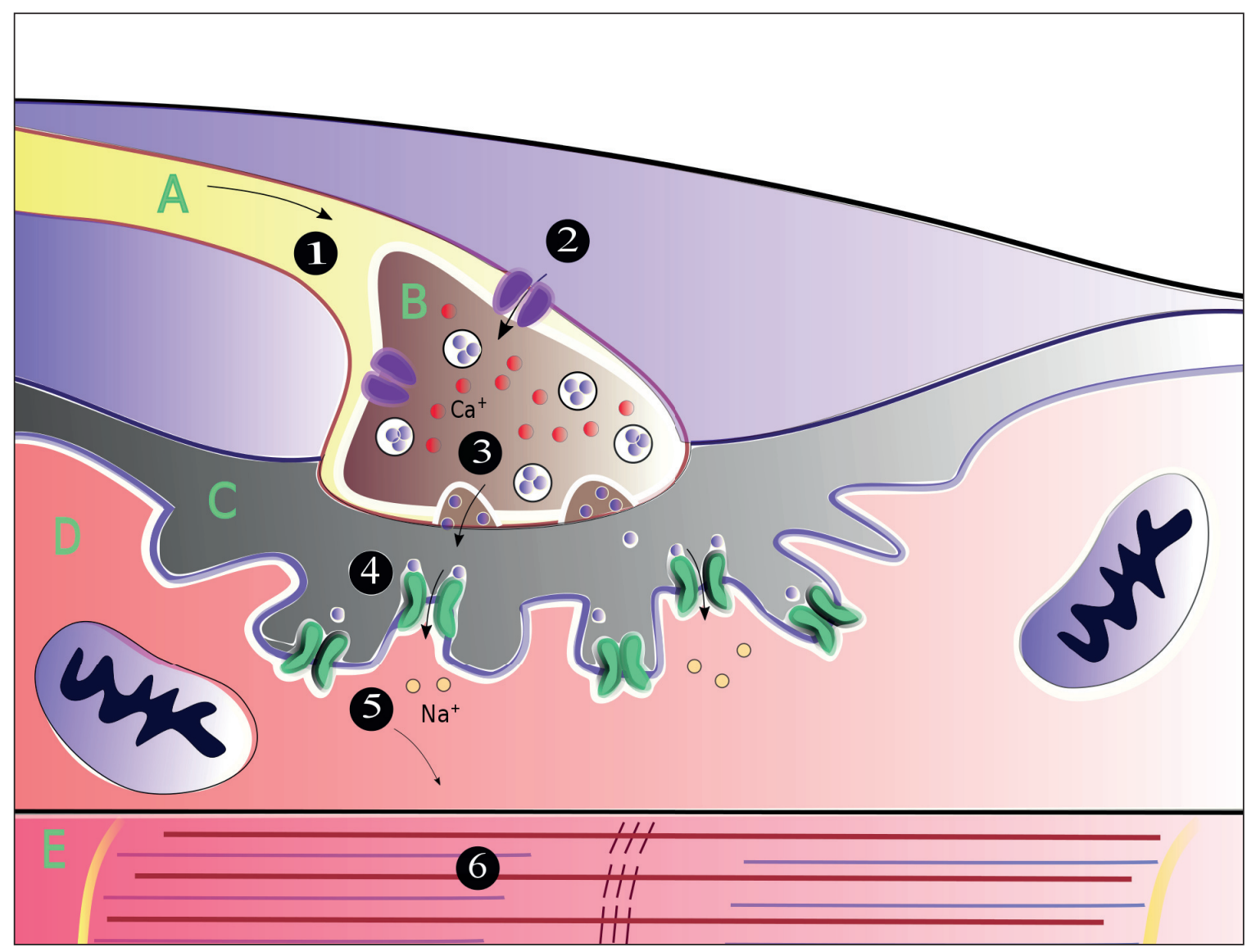

Figure 1. Schematic presentation of neuromuscular junction. (1) Nerve impulse reaches the nerve ending. (2) It opens the voltage calcium channels triggering a calcium ion influx. (3) Vesicles with acetylcholine fuse with the presynaptic membrane and the transmitter is excreted into the synaptic cleft. (4) Acetylcholine binds to the postsynaptic nicotinic receptors and opens the sodium ion channels. (5) Sodium ions enter the muscle fiber. (6) Sodium ion influx triggers the action potential in the myofibrils and causes muscle contraction. $\mathrm{A}=$ motor neuron axon, $\mathrm{B}=$ axon terminal, $\mathrm{C}=$ synaptic cleft, $\mathrm{D}=$ muscle cell, $\mathrm{E}=$ myofibril. 
mon characteristics is ability to inhibit AChE, an enzyme crucial for the breakdown of acetylcholine. They can be divided into irreversible and reversible inhibitors, with organophosphates belonging to the former group and carbamates belonging to the latter one. Some of them have a role in medicine as therapeutic agents and are used (i) in treatment of poisonings with anticholinergic drugs physostigmine, (ii) Alzheimer's disease - rivastigmine, and donepezil, (iii) glaucoma - phospholine (echothiophate), (iv) for antagonizing competitive neuromuscular blockade after the end of the operations - neostigmine and (v) for treatment of myasthenia gravis and (vi) in prophylaxis of the intoxications with nerve agents - pyridostigmine (4-6), while the others are being used as insecticides - parathion, paraoxon, malathion, dichlorvos, carbaryl, carbofuran (7, 8). A special group of organophosphorus anticholinesterases are nerve agents - tabun, sarin, soman and O-ethyl S-[2-(diisopropylamino)ethyl] methylphosphonothioate (VX) - that have a potential military use as chemical weapons of mass destruction $(2,9)$.

The physiological role of $\mathrm{AChE}$ is to terminate action of acetylcholine, in order to prevent the overstimulation of the cholinoceptors. As a consequence, the inhibition of AChE leads to this overstimulation and various phenomena, signs and symptoms occur as a result of this action (10, 11). Clinical picture of anticholinesterase poisoning depends on the route of exposure (12) and on the quantity of the anticholinesterase in the organism, but includes miosis, bronchoconstriction, hypersalivation, bronchorrhoea, skeletal muscle fasciculations, bradycardia, hypotension, seizures and respiratory failure, the latter being the main cause of death $(9,13)$.

The topic of this mini-review is to elaborate on the mechanism of the anticholinesterase-induced respiratory failure.

\section{PERIPHERAL VERSUS CENTRAL ANTICHOLINESTERASES}

Ever since the organophosphorus nerve agents became known to mankind in the 1940s, a considerable body of literature was published on the clinical picture of intoxications induced by organophosphorus compounds (OPCs) and specifically nerve agents. Cause of death in most of the animal species investigated was respiratory failure (14), although is many publications a considerable attention was drawn to the cardiovascular collapse as an independent factor contributing to a lethal outcome (15).

Anticholinesterases impair the respiratory function in mammals depending on their ability to pass the haematoencephalic or blood-brain barrier (BBB). The ones that contain a quaternary $\mathrm{N}$-atom in their molecules are strongly ionized and hence hydrated and as such cannot pass the BBB, exerting their AChE-inhibiting effect only in the periphery, i.e. outside the CNS. Among the OPCs such examples are phospholine (echothiophate) iodide (16), while the most famous peripherally-acting carbamates are neostigmine and pyridostigmine, the latter being also used in prophylaxis against nerve agents (17).

The remaining anticholinesterases are, more or less, lipophilic and readily pass the $\mathrm{BBB}$ inhibiting thus the brain $\mathrm{AChE}$, as the most important target. Best examples of such molecules are nerve agents tabun, sarin, soman and VX, insecticides dichlorvos (DDVP) and paraoxon (metabolite of parathion) and the oldest known anticholinesterase carbamate, physostigmine, which had become a model-substance in pharmacological research $(15,18)$. Soman is so highly lipophilic, that it reaches the brain circulation just 1 min after IV injection and completely distributes throughout the brain tissue in only $3 \mathrm{~min}$ (19).

\section{PERIPHERAL COMPONENT OF ANTICHOLIN- ESTERASE-INDUCED RESPIRATORY DEPRESSION}

Exclusively peripherally acting anticholinesterases inhibit AChE in peripheral tissues, including bronchi and neuromuscular synapse. The pulmonary consequences include failure of AChE to destruct acetylcholine, leading to overstimulation of muscarinic receptors in smooth muscles of bronchi and in bronchial exocrine glands, leading to bronchoconstriction and bronchorrhoea (20).

Although this pulmonary muscarinic syndrome compromises the alveolar gas exchange and lead to hypoxaemia, the results of significant inhibition of AChE in diaphragm and intercostal muscles is considered more serious and more important for survival, although it depends on the animal species studied (14). Anticholinesterases usually in the beginning induce a slight increase in contractions of diaphragm, but longer-lasting surplus of acetylcholine in the vicinity of nicotinic receptors eventually lead to a Wedensky-type of depolarization block (21). The final outcome is a flaccid paralysis of respiratory muscles and death due to an asphyxia (22). In such cases, peripheral respiratory paralysis usually occurs after the animal was pretreated with atropine, while normal phrenic nerve discharges still can be recorded $(21,23)$.

\section{NAUROANATOMY OF RESPIRATORY NEURONS}

Respiration is a complex function driven by the groups of cholinergic neurons in the CNS. They can be divided into three groups: dorsal, ventral and pontine (24). Dorsal neurons are located in the medulla, close to Nucleus tractus solitarii and receive sensory signals from the vagal nerve (25). Ventral neurons are located in ventrolateral medulla and are divided into rostral, intermediate and caudal ones. Rostral neurons contain the pre-Bötzinger complex and are very important generator of central respiratory drive. As a matter of fact, pre-Bötzinger complex is a respiratory oscillator. Bilateral injections of OPCs into this group of neurons induce apnea that can be reversed by 


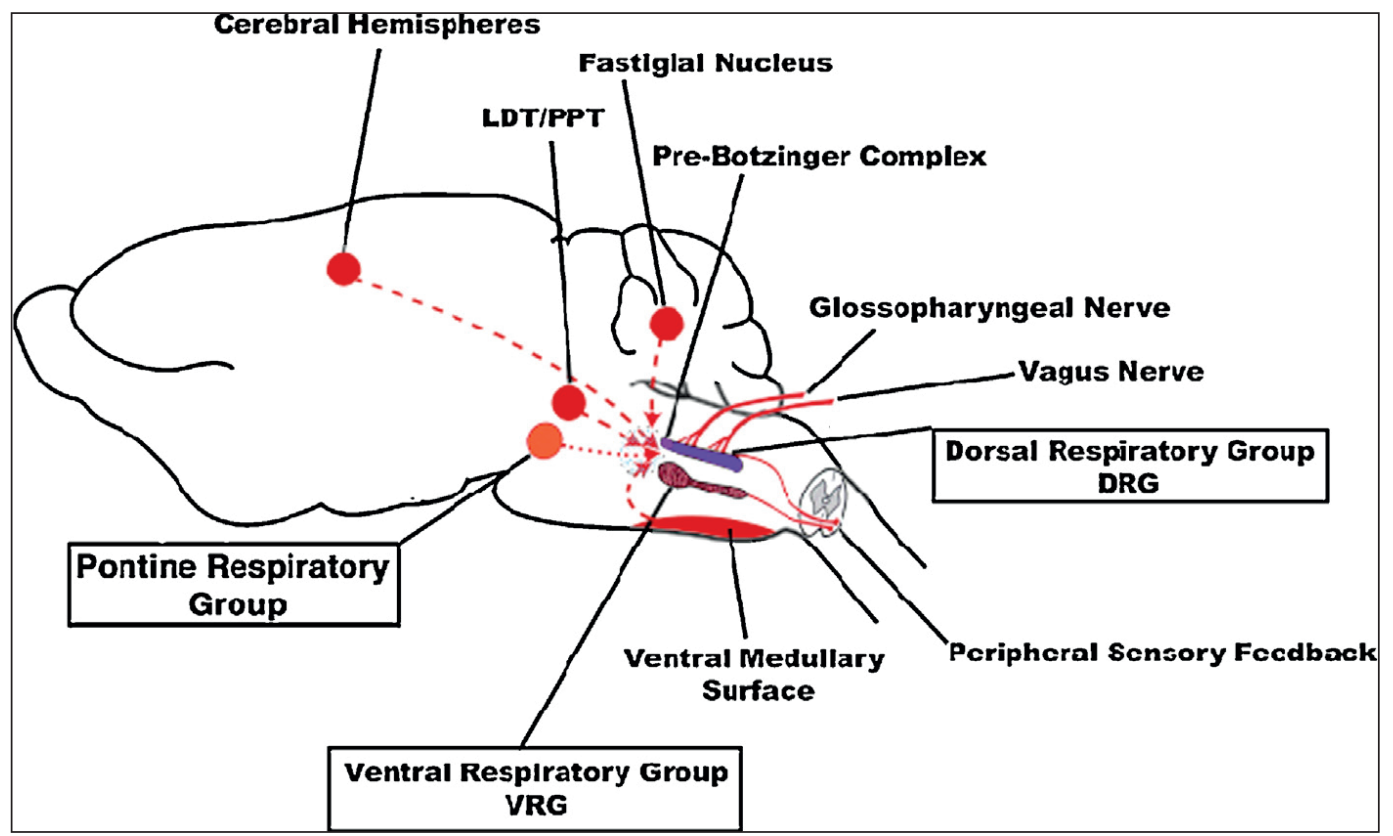

Figure 2. Distribution of neuron groups important for respiration in rat brain and their projections.

atropine (25). According to other authors, ventral respiratory group of neurons consists of five separate subgroups: caudate, intermediate, rostral, pre-Bötzinger and Bötzinger (24). Pontine group is known as pneumotaxic centre. It consists of two groups of neurons - medial parabrachial nucleus and Kölliker-Fuse nucleus (24). Its main function is to switch from inspiration to expiration (25). It is believed that pre-Bötzinger and Bötzinger complexes and rostral ventrolateral medulla contain the neuronal circuits of the respiratory central pattern generator (26). The special details of the distribution of these groups of neurons are shown in Figure 2.

\section{CENTRAL COMPONENT OF ANTICHOLINES- TERASE-INDUCED RESPIRATORY DEPRESSION}

Nerve agents have tendency to produce the highest levels of AChE inhibition in the ponto-medullar region where these nuclei are located (27). It automatically means that in these discrete brain regions acetylcholine builds up the most. Indeed, anticholinesterases, depending on the dose injected, first stimulate respiration $(21,22)$.

Higher doses of anticholinesterases induce respiratory depression. It can be manifested as bradypnoea, prolonged pause between inspirations and expirations and, in most severe cases, as total desynchronisation of the central respiratory stimuli, resulting in chaotic contractions of respiratory muscles that make the respiration inefficient and lead to hypoxaemia and hypercapnia (28).

Local administration of soman into the intermediate part of the ventral surface of medulla oblongata profoundly affected both the respiratory and cardiovascular functions. All these effects were reproduced after replacing soman with muscarinic receptor agonist oxotremorine and reversed by atropine, implying the involvement of muscarinic mechanisms (29).

At the same time, nicotine does not only act as a powerful poison of respiratory centres, since mecamylamine, a centrally-acting nicotinic receptor antagonist can restore the OPC-induced respiration and exerts significant protection of mice poisoned with soman (30). These and other findings suggest the involvement of both muscarinic and nicotinic receptors in the anticholinesterase-induced central respiratory failure (31).

What is probably more important than the elucidation of the primary receptor pathway of the central anticholinesterase-induced respiratory failure is the fact that most of the authors ascertained that the central respiratory component was endangered even by lower doses of organophosphates and carbamates. For example, in the anaesthetized cat, only 1 LD50 of soman was needed to cause a central respiratory paralysis, in comparison with 14 LD50 of soman needed for obtaining the neuromuscular blockade (32). These cats were instrumented in such a way that gastrocnemius muscle was electrically stimulated in situ, allowing thus the peripheral neuromuscular function to be checked irrespectively of the discharges from the $\mathrm{CNS}$, which were at the same time monitored in the proximal part of the phrenic nerve. In this experiment, Rickett et al (32) found that a 14-fold higher dose of soman was needed to block the sciatic nerve-gastrocnemius preparation in situ, than to cause a central cessation of phrenic nerve discharges.

This central versus peripheral ratio varied, depending on both the animal species and the anticholinesterase used. Under the same conditions, dose capable of causing central and peripheral respiratory blockade in guinea pigs 
were 38 and $400 \mathrm{mcg} / \mathrm{kg}$ IV for soman (ratio 1:10) and 82 and $650 \mathrm{mcg} / \mathrm{kg}$ IV for sarin (ratio 1:8) (33). It was shown that VX that has the slowest onset of action, has roughly the equal potential for central and peripheral AChE inhibition and respiratory impairment $(18,34)$. The same applies to tetraethyl pyrophosphate (TEPP) poisoning in cats (22). As already mentioned, soman is a typical example of predominantly centrally acting anticholinesterase nerve agents, where the activity of respiratory centre is impaired first, followed by the neuromuscular transmission and pulmonary muscarinic syndrome, which is of definitely least clinical significance (14). At the same time, TEPP and sarin in rabbits first affect the neuromuscular transmission and then cause a respiratory arrest (21).

\section{THERAPEUTIC REGIMENS FOR ANTICHOLIN- ESTERASE-INDUCED RESPIRATORY DEPRESSION}

From the therapeutic point of view, pulmonary muscarinic syndrome can be easily treated with muscarinic receptor antagonist atropine (35), which remains without any effect on nicotinic receptors of the neuromuscular junction even when applied in very high doses $(21,36)$. Additional proof that bronchoconstriction, bronchorrhoea and bradycardia are of a purely peripheral nature consists in a finding that they can be effectively treated even with $\mathrm{N}$-methyl atropine, a quaternary derivative of atropine that cannot pass the BBB (33).

Use of a ganglionic blocker pentamethonium (C5) or a classical neuromuscular nicotinic receptor antagonist d-tubocurarine assures protection against endogenous acetylcholine-induced toxicity resulting from poisonings with nerve agents $(22,37)$. However, since in the clinical settings it is not easy to find the right dose of nicotinic receptor antagonists that would not be paralyzing per se, peripheral nicotinic receptors are usually treated with oximes, as AChE reactivators $(2,36)$. They act as chelators that remove the inhibitor from the active centre of $\mathrm{AChE}$ and thus restore the enzyme's activity $(11,38)$.

Therapeutic implications of centrally acting anticholinesterases include use of atropine or even more lipophilic antimuscarinic agent scopolamine. In a vast range of doses $(0.5-10 \mathrm{mg} / \mathrm{kg}$ ) and routes of administration (IV, IM, SC), atropine eliminates signs of central respiratory depression induced by nerve agents $(7,14,23)$, while $\mathrm{N}$ methylatropine remains without any effect even after administration of the 100-fold equimolar doses proving thus the central site of the atropine therapeutic action (7). Atropine $2 \mathrm{mg} / \mathrm{kg}$ IV was able to counteract the respiratory arrest and bradycardia induced by microinjections of sarin into the lateral reticular nucleus of the rabbit medulla (39). At the same time, there are some limits to the effectiveness of atropine only regimens against somaninduced respiratory depression in guinea pigs - dose of $10 \mathrm{mg} / \mathrm{kg}$ IV is efficacious after administration of 2 LD50, partially effective after 5 LD50 and totally ineffective after 10 LD50 of soman (40).

Part of the treatment protocols for patients poisoned with anticholinesterases is treatment with atropine and oxime, in order to manage both the central muscarinic and peripheral muscarinic and nicotinic signs of intoxication, respectively $(11,41)$. Although not efficient as a reactivator of tabun- or soman-inhibited AChE, pralidoxime, in the form of chloride (2-PAM) or methanesulphonate (P2S) has been the most widely used oxime, effective against sarin and VX, but also against many anticholinesterase insecticides (11). It has been determined that the maintenance of pralidoxime minimum plasma concentration of $4 \mathrm{mg} / \mathrm{l}$ is crucial for its therapeutic effect (42). Since it falls bellow this level after 1.5-2 $\mathrm{h}$ after the IV bolus administration of $1 \mathrm{~g}$ of 2-PAM, it is recommended that this oxime is administered as a continuous IV infusion at a rate of $0.5 \mathrm{~g} / \mathrm{h}$ (43). In the open field situation, however, IV route of administration might be too demanding for the health personnel trying to treat a number of seriously poisoned individuals and IM route therefore should be preferred, when a single dose of $500 \mathrm{mg}$ of pralidoxime should be injected. Such application, up to three times and separated with 20-min intervals, should not produce any adverse effects, while the same therapeutic regimen in individuals already taking pralidoxime $\mathrm{PO}$ as prophylaxis may induce a reversible visual impairment (44).

It is generally accepted that soman and other centrallyacting AChE inhibitors via cholinoceptor hyperstimulation start a vicious circle that ends up with glutamatergic excitatory discharges that clinically manifest themselves as seizures and leave the survivors with serious brain damage (45, 46). It is not clear what the relation between the onset of seizures and the occurrence of respiratory depression is in soman-poisoned animals, since most of the cited experiments have been performed under urethane anaesthesia (47). In non-anaesthetised animals, loss of consciousness coincided with seizures and respiratory depression occurred immediately thereafter (33). In epilepsy, a considerable number of patients with seizures developed a central apnoea and hypoxaemia (48) and it is therefore logical to assume that then same applies to the seizures induced by acetylcholinesterase inhibitors. For the same reason, it seems plausible to conclude that administration of diazepam, as anticonvulsant, is beneficial for the treatment of both conditions (11).

Although the efficacy of atropine in preventing the central respiratory depression induced by anticholinesterases suggests the obvious role of muscarinic receptors, nicotinic receptors are likely to be involved, too and this mechanism probably includes some non-cholinergic transmitters, such as endogenous opioids. Indeed, it seems that, in presence of soman and atropine, it is the stimulation of nicotinic presynaptic receptors that induces the liberation of glutamate (49). There is some evidence that this pathway can also represent a link between cholinergic and glutamatergic neurons that in turn exerts control over release of endogenous opioids in the CNS (50). 


\section{CONCLUSION}

Only peripherally-acting anticholinesterases induce death by overstimulating with excess of acetylcholine the nicotinic receptors at the neuromuscular junction, while muscarinic pulmonary syndrome is of minor importance for survival. Centrally-acting anticholinesterases inhibit $\mathrm{AChE}$ in the pontomedullary region and impair the functioning of the respiratory centre neurons, since they receive numerous cholinergic inputs. Phrenic nerve discharges cease in these cases at doses of anticholinesterases much lower than those needed for inducing peripheral neuromuscular block. The recommended therapy includes atropine that blocks central and peripheral muscarinic receptors and oximes, which reactivate the inhibited $\mathrm{AChE}$ mainly outside the CNS, but also diazepam, in order to control seizures. Possible involvement of central nicotinic receptors as well as the other neurotransmitter systems glutamatergic, opioidergic - necessitates further research of additional antidotes.

\section{REFERENCES}

1. Hrobak PK. Nerve agents: implications for anesthesia providers. AANA J 2008;76:95-7.

2. Bailey AM, Barker SN, Baum RA, Chandler HE, Weant KA. Being prepared: Emergency treatment following a nerve agent release. Adv Emerg Nurse J 2014;36:22-33.

3. King JM, Hunter JM. Physiology of the neuromuscular junction. Br J Anaesth CEPD Reviews 2002;2(5):129-33.

4. Komlova M, Musilek K, Dolezal M, Gunn-Moore F, Kuca K. Structure-activity relationship of quaternary acetylcholinesterase inhibitors - outlook for early myasthenia gravis treatment. Curr Med Chem 2010;17:1810-24.

5. Kraus CL, Trivedi RH, Wilson ME. Intraocular pressure control with echothiophate iodide in children's eyes with glaucoma after cataract extraction. J AAPOS 2015;19:116-8.

6. Watkins JW, Schwarz ES, Arroyo-Plasencia AM, Mullins ME, Toxicology Investigators Consortium Investigators. The use of physostigmine by toxicologists in anticholinergic toxicity. J Med Toxicol 2015;11:179-84.

7. Houze P, Pronzola L, Kayouka M, Villa A, Debray M, Baud FJ. Ventilatory effects of low-dose paraoxon result from central muscarinic effects. Toxicol Appl Pharmacol 2008;233:186-92.

8. Chahal KS, Prakash A, Majeed ABA. The role of multifunctional drug therapy against carbamate induced neuronal toxicity during acute and chronic phase in rats. Environ Toxicol Pharmacol 2015;40:220-9.

9. Albuquerque EX, Pereira EFR, Aracava Y, Fawcett WP, Oliveira M, Randall WR, Hamilton TA, Kan RK, Romano JA Jr, Adler M. Effective countermeasure against poisoning by organophosphorus insecticides and nerve agents. Proc Natl Acad Sci 2006;103:13220-5.
10. Sivilotti MLA, Bird SB, Lo JCY, Dickson EW. Multiple centrally acting antidotes protect against severe organophosphate toxicity. Acad Emerg Med 2006;13:359-64.

11. Antonijević B, Stojiljković MP. Unequal efficacy of pyridinium oximes in acute organophosphate poisoning. Clin Med Res 2007;5:71-82.

12. Franz DR, Hilaski R. Sequence of cardiorespiratory effects of soman altered by route of administration. Toxicol Lett 1990;51:221-5.

13. Bajgar J. Complex view on poisoning with nerve agents and organophosphates. Acta Med (Hradec Kralove) 2005;48:3-21.

14. De Candole CA, Douglas WW, Evans CL, Holmes R, Spencer KEV, Torrance RW, Wilson KM. The failure of respiration in death by anticholinesterase poisoning. $\mathrm{Br}$ J Pharmacol 1953;8:466-75.

15. Balali-Mood M, Saber H. Recent advances in the treatment of organophosphorous poisonings. Iran J Med Sci 2012;37:74-91.

16. Amos ML, Smith ME. Effect of organophosphate administration on the expression of pro-opiomelanocortin-derived peptides in motoneurones. Neurotoxicology 1998;19:789-97.

17. Bajgar J, Fusek J, Kassa J, Kuca K, Jun D. Chemical aspects of prophylaxis against nerve agent poisoning. Curr Med Chem 2009;16:2977-86.

18. Bajgar J, Fusek J, Kassa J, Jun D, Kuca K, Hajek P. An attempt to assess functionally minimal acetylcholines$\overline{\text { terase activity necessary for survival of rats intoxicated }}$ with nerve agents. Chem-Biol Interact 2008;175:281-5.

19. Göransson Nyberg A, Cassel GE. Dramatic increase in cerebral blood flow following soman intoxication if signs of symptoms can be seen. Adv Toxicol 2015; Article ID 935069, 9 pages, 2015. doi:10.1155/2015/935069.

20. Newmark J. Therapy for nerve agent poisoning. Arch Neurol 2004;61:649-52.

21. Wright PG. An analysis of the central and peripheral components of respiratory failure produced by anticholinesterase poisoning in the rabbit. J Physiol 1954;126:52-70.

22. Douglas WW, Matthews PBC. Acute tetraethylpyrophosphate poisoning in cats and its modification by atropine or hyoscine. J Physiol 1952;116:202-18.

23. Stewart WC. The effects of sarin and atropine on the respiratory center and neuromuscular junctions of the rat. Can J Biochem Physiol 1959;37:651-60.

24. Bonham AC. Neurotransmitters in the CNS control of breathing. Respir Physiol 1995;101:219-30.

25. Carey JL, Dunn C, Garspari RJ. Central respiratory failure during acute organophosphate poisoning. Resp Physiol Neurobiol 2013;189:4013-10.

26. Lindsey BG, Rybak IA, Smith JC. Computational models and emergent properties of respiratory neural network. Compr Physiol 2012;2:1619-70.

27. Bajgar J, Hajek P, Slizova D, Krs O, Fusek J, Kuca K, Jun D, Bartosova L, Blaha V.Changes of acetylcholinesterase activity in different rat brain areas following intoxication with nerve agents: biochemical and histochemical study.Chem Biol Interact 2007;5:14-21. 
28. Chang F-C T, Foster RE, Beers ET, Rickett DL, Filbert MG. Neurophysiological concomitants of soman-induced respiratory depression in awake, behaving guinea pigs. Toxicol Appl Pharmacol 1990;102:233-50.

29. Gillis RA, Walton DP, Quest JA, Namath IJ, Hamosh P, Dretchen KL. Cardiorespiratory effects produced by activation of cholinergic muscarinic receptors on the ventral surface of the medulla. J Pharmacol Exp Ther 1988;247:765-72.

30. Hassel B. Nicotinic mechanisms contribute to somaninduced symptoms and lethality. Neurotoxicology 2006;27:501-7.

31. Chatonnet F, Boudinot E, Chatonet A, Tayse L, Daulon S, Champagnat J, Foultz AS. Respiratory survival mechanisms in acetylcholinesterase knockout mouse. Eur J Neurosci 2003;18:1419-27.

32. Rickett DL, Glenn JF, Beers ET. Central respiratory effects versus neuromuscular actions of nerve agents. Neurotoxicology 1986;7:225-36.

33. Adams GK III, Yamamura HI, O'Leary JF. Recovery of central respiratory function following anticholinesterase intoxication. Eur J Pharmacol 1976;38:101-12.

34. Shih T-M, Kan RK, McDonnough JH. In vivo cholinesterase inhibitory specificity of organophosphorus nerve agents. Chem-Biol Interact 2005;157-158:293-303.

35. Lipp JA. Effect of atropine upon the cardiovascular system during soman-induced respiratory depression. Arch Int Pharmacodyn Ther 1976;220:19-27.

36. Johnson DD, Stewart WC. The effects of atropine, pralidoxime, and lidocaine on nerve-muscle and respiratory function in organophosphate-treated rabbits. Can J Phisiol Pharmacol 1970;48:625-30.

37. Gupta RC, Dettbarn W-D. Potential of memantine, $\mathrm{d}$-tubocurarine and atropine in preventing acute toxic myopathy induced by organophosphate nerve agents: soman, sarin, tabun and VX. Neurotoxicology 1992;13:500-14.

38. Bajgar J. Optimal choice of acetylcholine reactivators for antidotal treatment of nerve agent intoxication. Acta Med (Hradec Kralove) 2010;53:207-11.

39. Stewart WC, Anderson EA. Effect of a cholinesterase inhibitor when injected into the medulla of the rabbit. J Pharmacol Exp Ther 1968;162:309-18.
40. Worek F, Szinicz L. Analysis and cardiovascular and respiratory effects of various doses of soman in guineapigs: Efficacy of atropine treatment. Arch Int Pharmacodyn Ther 1993;325:96-112.

41. Brown RV. The effects of intracysternal sarin and pyridine-2-aldoxime methyl methanesulphonate in anaesthetized dogs. Br J Pharmacol 1960;15:170-4.

42. Sudvall A. Minimum concen6rations of P2S which reverse neuromuscular block. Biochem Pharmacol 1961;8:413-7.

43. Thompson DF, Thompson GD, Greenwood RB, Trammel HL. Thereapeutic dosing of pralidoxime chloride. Drug Intell Clin Pharm 1987;21:590-3.

44. Holland P, Parkes DC. Plasma concentrations of the oxime Pralidoxime Mesylate (P2S) after repeated oral and intramuscular administration. Br J Industr Med 1976;33:43-6.

45. Figueiredo TH, Qashu F, Apland JP, Aroniadou-Anderjaska V, Souza AP, Braga MFM. The GluK1 (GluR5) kainate alpha-amino-3-hydroxy-5-methyl-4-isoxazolepropionic acid receptor antagonist LY293558 reduces soman-induced seizures and neuropathology. J Pharmacol Exp Ther 2011;336:303-12.

46. Chen J, Pan H, Chen C, Wu W, Iskandar K, He J, et al. (-)-Phenserine Attenuates Soman-Induced Neuropathology. PLOS ONE 2014;9(6):e99818. doi:10.1371/

journal.pone.0099818

47. Cain DP, Raithby A, Corcoran ME. Urethane anesthesia blocks the development and emission of kindled seizures. Life Sci 1989;44:1201-6.

48. Nashef L, Walker F, Allen P, Sander JWAS, Shorvon SD, Fish DR. Apnoea and bradycardia during epileptic seizures: relation to sudden death in epilepsy. J Neurol Neurosurg Psychiatry 1996;60:297-300.

49. Alkondon M, Albuquerque EX, Pereira EF. Acetylcholinesterase inhibition reveals endogenous nicotinic modulation of glutamate inputs to CA1 stratum radiatum interneurons in hippocampal slices. Neurotoxicology. 2013;36:72-81.

50. Bach FW, Yaksh TL. Release of beta-endorphin immunoreactivity from brain by activation of a hypothalamic N-methyl-D-aspartate receptor. Neuroscience 1995;65:775-83. 